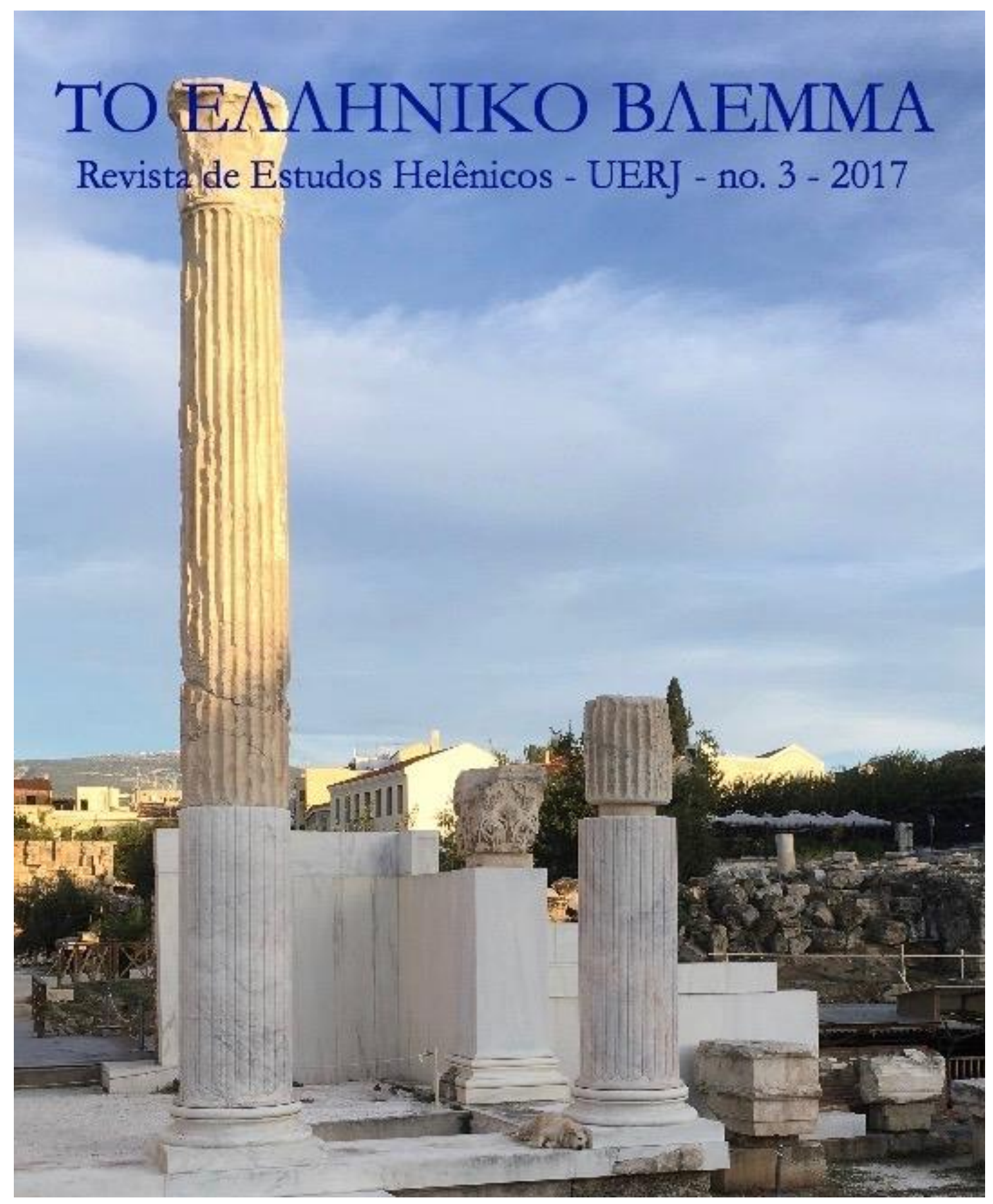




\title{
DESCONSTRUINDO O CONCEITO DE BÁRBARO COM A AJUDA DE KAVÁFIS ${ }^{1}$
}

\author{
Ioannis Petropoulos \\ Universidade Democriteana da Trácia \\ Centro de Estudos Helênicos - Grécia, Universidade de Harvard
}

\section{Resumo}

A primeira parte deste artigo discute o conceito de "bárbaro" na antiga sociedade grega e em sua literatura. Como usado a partir de meados do século V a.C., o termo serve como um marcador linguístico e cultural, denotando ou implicando a barreira conceitual entre "nós" (gregos) e "eles" (o resto do mundo), portanto entre gregos e 'outros'. No entanto, em alguns casos, essa divisão pode entrar em colapso com o uso não generoso dos gregos. A segunda parte do artigo examina o poema clássico de Kavafy "À espera dos bárbaros" (1904) à luz do antigo conceito de "bárbaro". Lançando mão de uma troca dialógica de perguntas e respostas entre dois cidadãos do final do Império Romano, o poema dramatiza o diálogo mental e a relação conceitual que surge quando, como os antigos, distinguimos entre nós e o "outro bárbaro". Por que os bárbaros de Kavafy são uma "solução" e "libertação" (ambos sugeridos por $\lambda$ úøı)? Por que seus não-bárbaros são paradoxalmente atraídos por eles? Como já foi proposto por outros, os bárbaros de Kaváfis podem pertencer ao clima de decadência literária do final do século XIX ou à atmosfera de incerteza política e declínio no Egito colonial ou, como sugiro, no Reino da Hélade, ainda em luta contra o império Otomano. Mais amplamente definido, seus "bárbaros" podem representar o alter ego decadente de sua sociedade.

\begin{abstract}
The first part of this article discusses the concept of the 'barbarian'in ancient Greek society and literature. As used from the mid- $5^{\text {th }}$ century BC on, the term serves as a linguistic and cultural marker, denoting or implying the conceptual barrier between 'us' (Greeks) and 'them' (the rest of the world), hence between Greeks and 'others'. Yet in some instances this divide might collapse at the unflattering expense of Greeks. The second part of the article examines Kavafy's classic poem 'Waiting for the barbarians' (1904) in the light the ancient concept of the 'barbarian'. Cast as a dialogical exchange of questions and answers between two citizens of the late Roman Empire, the poem dramatises the mental dialogue and conceptual relation that arises when, like the ancients, we distinguish between ourselves and the 'barbarian other'. Why are Kavafy's barbarians a 'solution' and 'liberation' (both suggested by גúois)? Why are his non-barbarians paradoxically attracted to them? As has been proposed by others, Kavafy's barbarians may belong to the climate of late 19th century literary décadence or to the atmosphere of political uncertainty and decline in colonial Egypt or, as I suggest, in the Kingdom of Hellas, still caught in a struggle against the Ottoman Empire. More broadly defined, his 'barbarians' may represent his society's decadent alter ego.
\end{abstract}

\footnotetext{
${ }_{1}^{1}$ Agradecimentos são devidos à Professora Maria Cecília de Miranda Nogueira Coelho, aos seus colegas e aos alunos do Programa de Pós-graduação em Filosofia, Núcleo de Estudos Antigos e Medievais (Neam), da Universidade Federal de Minas Gerais, Brasil, pelo convite para realizar uma conferência na qual esse artigo foi baseado e pelos seus comentários; igualmente, à senhora Maro Prevélaki e ao Professor Frederick Ahl pelo incalculável retorno; e à Professora Fernanda Lima pela tradução perita do meu texto original em inglês.
} 
Do mesmo modo que o título da mesa redonda em que foi apresentado o presente trabalho indica², "bárbaro", como utilizado pelos gregos antigos, constituiuse como um conceito e, mais especificamente, como uma "construção" mental ou um

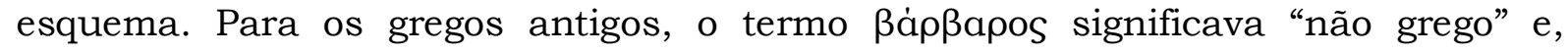
consequentemente, "não-eu" (ou "não-nós") seja em um sentido neutro (não marcado) ou em um sentido negativo (marcado), do mesmo modo como a palavra brasileira "gringo" pode ser pejorativa ou neutra. Com efeito, ßápßapos era o equivalente ao conceito de "outro" como caracterizado em uma variedade de disciplinas que vão da filosofia à psicanálise e à teoria pós-colonial. O que é, então, "outro" ou "o outro"? Para citar uma definição padrão, o termo outro, em termos gerais, "refere-se a um polo de um relacionamento entre um sujeito e uma coisa ou pessoa definida ou constituída como um não-eu que é diferente ou outro".3 "Outro" é o "não-eu", o diferente de mim: o meu conceito de outro é baseado em minha relação conceitual com ele ou ela. Uma das categorias abrangentes de "outro" no pensamento grego antigo era o termo ßápßapos.

Bápßapos é um termo linguístico gerado, ao que parece, por uma reduplicação onomatopaica, imitando sons ou falas estrangeiros incompreensíveis. Bápßapos,

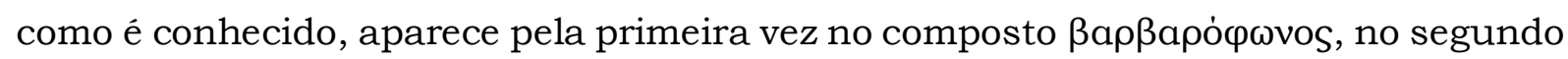
canto da Iliada de Homero, no Catálogo das naus, no qual se refere, em um sentido não valorativo, aos Cários como os que têm "uma fala estrangeira"(líada 2, 867).

O composto prenuncia uma atitude que estava para se tornar comum nos séculos V e IV a.C.: a tendência do grego para definir a "helenidade" pelo critério cultural de se falar grego. Voltarei a esse ponto em breve. Nesse interim, eu gostaria de ressaltar que, embora a poesia homérica e arcaica geralmente estivessem bem atentas aos não-gregos, essa distinção não foi explorada ou aprofundada, diferente do que aconteceu em outros tipos de discurso, como a retórica ou o drama. Em Homero, o conceito de "outro" é estruturado nos polos opostos de "mortal" e "imortal", homem e deus (com d minúsculo) e, em última instância, "herói" (semideus) e "deus". Entre os polos, reside a categoria das feras. A maioria dos monstros pode ser imortal e os que não o são estão mais próximos do sobre-humano do que os heróis. Eles são elementos do discurso homérico em relação ao que significa ser humano.

Um monstro é, usualmente, um híbrido, um mestiço que combina duas ou mais espécies de seres e pode, ao mesmo tempo, ter uma anatomia exagerada: um

\footnotetext{
2 "(Des)construção do conceito de bárbaro no discurso retórico na tragédia e filosofia, nos séculos V e IV a.C."

${ }^{3}$ No Dict. Of Critical Theory, verificar "outro".
} 


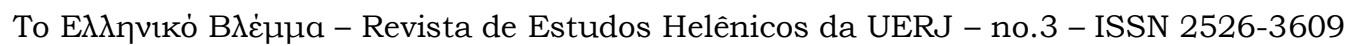

Centauro é meio-cavalo, meio-homem; os Hekatoncheires têm cem braços; a Quimera (Chimaira) é, em parte, uma jovem cabra e, em parte, um leão com um ridículo rabo de serpente; Cérbero é um cão com muitas cabeças que come homens. Um monstro está próximo de ser uma fera e um animal, como um herói também pode ser. Por exemplo, na Odisseia, o ciclope Polifemo come homens, da mesma maneira que Cérbero faz no mundo subterrâneo, bem como os cães e abutres ao final de uma batalha na Iliada. Polifemo, anatomicamente um monstro, comporta-se como uma fera. Apesar de ser um monstro, ele é, no entanto, diretamente, um ser humano e, mais do que isso, um herói!

A Odisseia não deixa dúvidas sobre seu caráter heroico e mortal. Polifemo é, afinal, o filho de Poseidon e uma ninfa. Ele é descrito como um herói descomunal, de força extraordinária. Assim, o Ciclope é realmente um herói hiperbólico. Ele é descrito como "investido de notável força", uma frase usada para dois Ajax na Míada. Suas observações de desprezo, a respeito de Odisseu ser insignificante e fraco, indicam uma perspectiva heroica, na medida em que ele dá ênfase à força e à estatura na composição de um herói. Acima de tudo, ele é capaz de selvageria sanguinária que culmina em seis atos de canibalismo. Ele realiza o que Aquiles é capaz apenas de fantasiar no canto 22 da Miada, mas jamais realiza completamente apesar de seu frenesi.

Desejo salientar que os monstros não são um mero suspense e distração colorida nos mitos sobre heróis. Eles mostram, de várias maneiras, o terreno comum entre homem e mutante, homem e monstro, monstro e besta, homem e besta. Ao mesmo tempo, eles demarcam a fronteira entre natureza e cultura. Os heróis, em particular, têm um toque de DNA de monstro neles, muito como o casal super elegante Alcinoo e Arete na Odisseia, os quais são ambos descendentes de Eurimedonte, rei dos Gigantes. Heróis e homens se comportam como monstros perigosos (apresso-me para acrescentar que há monstros bons também!).

O objetivo de Homero é o de explorar o que significa ser humano, como muitos estudiosos já argumentaram. A poesia homérica o alcança amplamente, colocando homens contra outros homens em batalha, e, algumas vezes, contra deuses e monstros em outros contextos. Com exceção dos deuses que falam sua secreta, ininteligivel, mas presumível língua, as personagens de Homero nunca são definidas pela lingua. Culturas no épos não são explicitamente distintas por critérios linguísticos. Os troianos falam um grego impecável. (Eles diferem dos aqueus apenas por serem mais consensuais em seus discursos). ${ }^{4}$ Polifemo, a despeito de sua lenta

\footnotetext{
${ }^{4}$ Mackie (1996), passim.
} 
sagacidade, fala grego em hexâmetros perfeitos; e, a despeito de seu apetite por carne

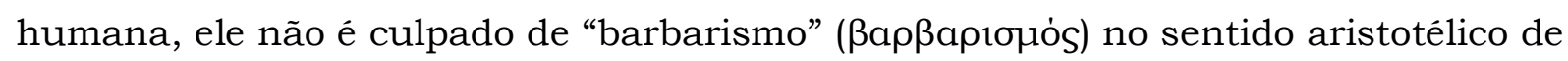
"incompetência em grego ou em uma língua estrangeira" (Poética 1458a 26).

Cultura e, em particular, a lingua se tornam pedra de toque da identidade grega em torno da metade do V século a.C., como é afirmado por Herôdoto, e, um pouco mais tarde, por Tucídides, ${ }^{5}$ e, de maneira controversa, por Isócrates (no seu Panegyrikos, um panfleto político publicado cerca de 380 a.C.). ${ }^{6}$ Como Edith Hall mostrou, a tragédia inventou e, de muitos modos, colocou em cena de maneira sensacional "a retórica em torno da antítese entre grego e Bárbaro" como uma dicotomia que incluía, mas dificilmente se limitava à linguagem. Entretanto, a língua continua a ser invocada como um atributo decisivo depois da expansão do mundo grego sob Alexandre e seus sucessores, quando a "língua comum" facilitou a comunicação entre gregos que falavam diferentes dialetos. ${ }^{7}$ Nos períodos Helenístico e Romano, os gregos se tornaram nostálgicos em relação à glória de seus ancestrais na Grécia continental (essa mesma era agora uma província). Nesse momento, espalhados entre povos não-gregos, em Seleucia e no Egito, os "gregos", como diz uma historiadora, "necessitavam de... critérios claros, fixos e duradouros de helenidade, que não fossem simplesmente absorvidos pela cultura dos seus sujeitos".8 O critério principal era a língua ática, consistentemente cultivada através da literatura e de uma educação literata, e servindo, além disso, como língua franca burocrática e comercial. A necessidade de critérios culturais continuou e, sem dúvida, foi intensificada quando esses gregos da diáspora se tornaram súditos do imperador romano.

Se me for permitida uma generalização abrangente: Os gregos sempre estiveram cintes de suas diferenças culturais em relação aos não-gregos, e , dependendo das circunstâncias históricas e dos gêneros literários, eles registraram essas diferenças de maneira neutra ou simpática, em um extremo, ou depreciativamente em outro - ou ainda em outros casos, de maneira ambivalente. Aristóteles considerou a hierarquia de exclusão do escravo e do livre um produto da natureza e, dado que os escravos eram, de regra, não-gregos, classificou "bárbaros" sob essa rígida taxonomia. Ele defendeu sua "alteridade" dos bárbaros citando a

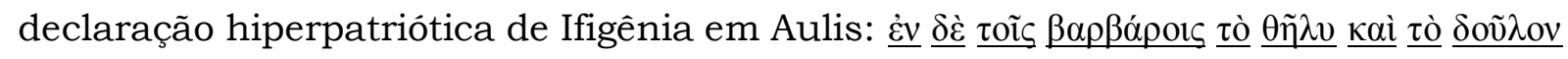

${ }^{5}$ Sobre Herôdoto, Tucídides e sobre a lingua grega como critério de identidade, ver Anson (2010), pp. 11, 16-18.

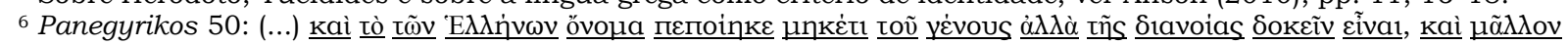

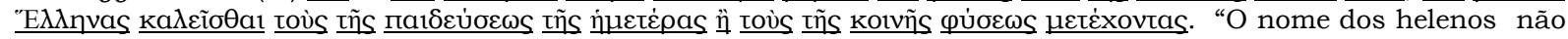
mais parece que se fez do elemento étnico (genos), mas da disposição (dianoia), e certamente, "helenos" são chamados os que partilham de nossa cultura (paideusis) mais do que os que partilham uma natureza comum (physis)."

7 Anson (2010), pp. 6-7.

${ }^{8}$ Morgan (1998), p. 23. 


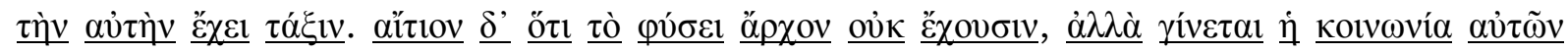

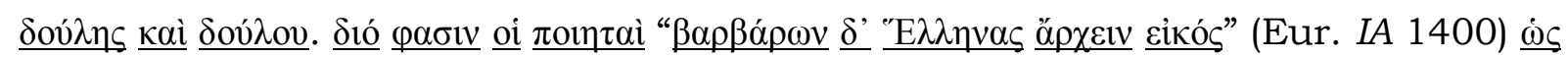

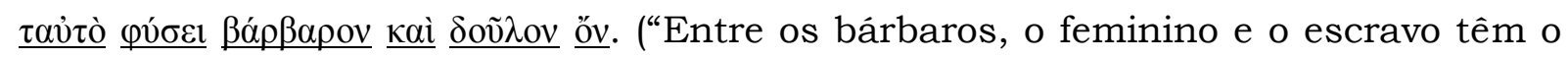
mesmo grau hierárquico. A causa é que não têm uma classe de governadores naturais, mas o casamento entre eles é de escrava e escravo. Assim dizem os poetas, 'É apropriado que os gregos devam governar os bárbaros'- assim, em relação à natureza, bárbaro e escravo são o mesmo." $)^{9}$ Um orador ateniense como Isócrates, ao insuflar uma guerra com a Pérsia, pode denunciar a fraqueza do inimigo. Por outro lado, gregos do período arcaico impulsionaram o comércio e a troca intercultural com não-gregos. A circulação de bens e ideias poderia os tornar mais tolerantes e, até mesmo, receptivos a culturas estrangeiras. ${ }^{10}$ Mitos apresentando genealogias estrangeiras também sugerem tal abertura, como E. Gruen argumenta. ${ }^{11}$ A guerra teria refreado a receptividade ou ajudado a erguer ou reforçar os estereótipos do bárbaro como o inimigo que repousava na oposição binária. No entanto, em geral, os contatos diversificados de gregos com não-gregos tornaram, pela complexidade, os relacionamentos e atitudes com os bárbaros mais sutis, os quais, muitas vezes, não eram tão reducionistas e demonizadores como fomos levados a entender. Eu ofereço três exemplos, os dois primeiros de Heródoto, a fim de mostrar as posições cambiantes ocupadas pelo conceito de "outro", no espectro mental do grego.

O general ateniense (ou melhor, almirante) Temístocles, horas antes da batalha naval de Salamina, em 480 a.C., exortou seus homens, ressaltando que eles defendiam algo mais do que sua terra natal. Como Herôdoto o descreve (8.83.1), "suas palavras eram sobre o contraste entre os aspectos muito melhores e piores que podem ser encontrados na natureza e constituição humanas", e Temístocles conclamou-os a escolher o melhor, a democracia. O historiador, ou sua fonte patriótica ateniense, retrata o comandante definindo Atenas através de antíteses depreciativas e autocongratulação. Se o relato de Herôdoto é preciso, Temístocles retoricamente mobilizou a vida-real, em uma dicotomia em preto-e-branco, entre despotismo e democracia. Os atenienses estavam lutando, verdadeiramente, para preservar a soberania e a democracia, e o estadista definiu não apenas o que estava em jogo, mas igualmente o traço fundamental da cultura ateniense.

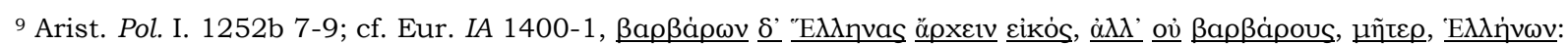

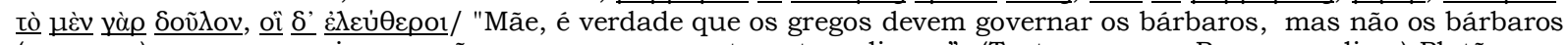
(governar) os gregos, pois, uns são escravos, enquanto outros, livres.” (Texto grego no Perseus online.) Platão, em contraste, questionou no Politicus 262 d-e a visão bipartite do ser humano que os difere em gregos e o resto, pela razão de "o resto" incluir incontáveis sub-categorias diferentes. Cf. E. Hall op. cit., p. 160.

${ }^{10}$ Prevelakis (2017), especialmente, pp. 56-7, sobre "circulação", segundo Gottmann.

${ }^{11}$ Gruen (2011); cf. Momigliano (1975).
} 


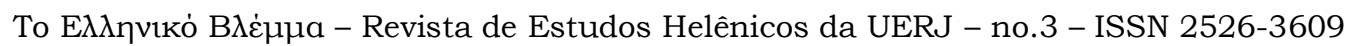

No livro 1, Herôdoto registra sua admiração pela prontidão dos persas em adotar costumes estrangeiros. Um desses costumes foi a pederastia, a qual, ele observa, foi aprendida dos gregos. Pederastia o leva, por sinédoque, ao tópico da educação aristocrática persa. O historiador agora registra, "por eras, às pessoas do sexo masculino de cinco a vinte anos, são ensinadas três coisas: equitação, manejo do arco e falar a verdade ( $\dot{\alpha} \lambda \eta \theta i \zeta \varepsilon \sigma \theta a 1) "(1.136)$. Os meninos estudantes persas são assim supostamente treinados para serem cavalheirescos e verdadeiros. Mas o que dizer sobre suas contrapartes gregas? Eles não aprendem equitação ou manejo do arco na escola - mas que dizer da verdade? Herôdoto está brincando com a ascensão da sofística na educação em Atenas. Jovens gregos, longe de serem instruídos em falar a verdade, dedicar-se-iam aos truques sofisticos. Aqui, novamente, um grego cita diferenças culturais em relação aos não-gregos, mas, desta vez, são os gregos que sofrem na comparação.

Meu terceiro exemplo de bárbaros como "outros" é retirado do Banquete de Platão, a partir do discurso de Pausânias em honra a Eros. O orador parece contradizer claramente a passagem já mencionada de Heródoto: “... Na Jônia e em muitos outros lugares, sob domínio bárbaro (isto é, Pérsia), ela (pederastia) é considerada vergonhosa. Os bárbaros a consideram (a pederastia) vergonhosa por causa de seu sistema tirânico de governo, assim como eles consideram a filosofia

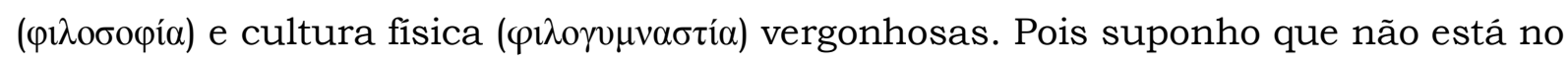
interesse dos governantes que seus súditos devam ter pensamentos ambiciosos ..." -Banquete 182b6-c212

Pausânias, um sofisticado homossexual ateniense, apresenta uma explicação sócio-política para o cultivo da homossexualidade em sua cidade que, acrescenta, vai de mãos dadas com a dedicação à filosofia e ao exercício físico e à nudez atlética. Em poucas frases, ele pinta a Pérsia como a quintessência de uma "sociedade fechada" e Atenas como a "sociedade aberta" por excelência. Sua menção à Jônia como estando sob domínio persa é notável, pois a Jônia era o coração espiritual de Atenas, e até 387/6 a.C., os gregos do continente asiático pertenciam ao Império ateniense. ${ }^{13}$ As implicações da observação de Pausânias se referem ao fato de que, após essa data, os gregos tinham regredido à condição de "bárbaros". Eles se tornaram, em certo sentido, decadentes para os atenienses, ou pelo menos para suas classes média e alta, levando-se em consideração a democracia, a homossexualidade, o esporte e a filosofia, não apenas como coisas da vida, mas como prova do "progresso" e da

\footnotetext{
12 Minha tradução.

${ }^{13}$ Dover (1980), p. 99 ad loc.
} 
superioridade grega. Tucídides, ao discutir como os Lacedemônios eram os primeiros no mundo a despir-se para a competição atlética, escreve: "Os primeiros helenos tinham muitos costumes semelhantes aos bárbaros do dia de hoje" (1.6.6). A adoção do nudismo no desporto era, por outras palavras, uma marca de progresso que nãogregos não tinham alcançado.

A decadência é o tema do poema de Kaváfis, "À espera dos Bárbaros"(1904):

\section{À Espera dos Bárbaros ${ }^{14}$}

O que esperamos na ágora reunidos?

É que os bárbaros chegam hoje. Por que tanta apatia no senado?

Os senadores não legislam mais?

É que os bárbaros chegam hoje.

Que leis hão de fazer os senadores?

Os bárbaros que chegam as farão.

Por que o imperador se ergueu tão cedo

e de coroa solene se assentou

em seu trono, à porta magna da cidade?

É que os bárbaros chegam hoje.

O nosso imperador conta saudar

o chefe deles. Tem pronto para dar-lhe

um pergaminho no qual estão escritos

muitos nomes e títulos.

Por que hoje os dois cônsules e os pretores

usam togas de púrpura, bordadas,

e pulseiras com grandes ametistas

e anéis com tais brilhantes e esmeraldas?

Por que hoje empunham bastões tão preciosos

de ouro e prata finamente cravejados?

É que os bárbaros chegam hoje, tais coisas os deslumbram.

Por que não vêm os dignos oradores derramar o seu verbo como sempre? É que os bárbaros chegam hoje e aborrecem arengas, eloqüências. Por que subitamente esta inquietude? (Que seriedade nas fisionomias!)

Por que tão rápido as ruas se esvaziam e todos voltam para casa preocupados? Porque é já noite, os bárbaros não vêm e gente recém-chegada das fronteiras

\footnotetext{
${ }_{14}$ Poesia Moderna da Grécia - Seleção, tradução direta do grego, prefácio, textos críticos e notas de José Paulo Paes-
} Editora Guanabara, Rio de Janeiro, 1986. 
diz que não há mais bárbaros.

Sem bárbaros o que será de nós?

Ah! eles eram uma solução.

O poema evoca uma atmosfera de tédio e ỏnрaรia comparável talvez ao clima de tédio no Satyricon, de Fellini, ou na Dolce Vita. A troca quase teatral de perguntas e respostas entre dois cidadãos anônimos não só estabelece o ritmo, ${ }^{15}$ mas evoca

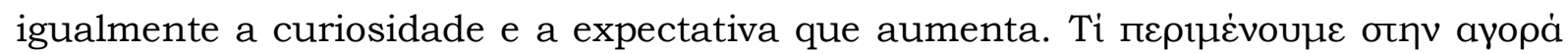

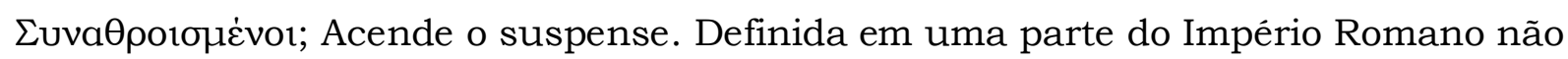
especificada, a "conversa" tem início em um período do um dia, terminando ao pôrdo-sol.

A voz que questiona é genuinamente alguém que ignora as razões da comoção que provoca a troca. Suas perguntas são uma crítica à cidade e aos concidadãos. ${ }^{16}$ As perguntas esboçam um estado de coisas bizarro no império, e, ao mesmo tempo, mostram os critérios e os índices da cultura greco-romana: o espaço institucional do fórum (1); o Senado (34); o imperador como a autoridade suprema (8-10); os cônsules e pretores (5-20); os oradores públicos (23-4); os uniformes oficiais e as cerimônias, a língua oficial.17 A cultura imperial é imaginada para ser diferente, pelo menos superficialmente, da cultura dos bárbaros. Algo estranho está em andamento. O fórum está cheio de cidadãos. O senado não exerce sua função normal de legislar (mais uma vez, 3-4). O imperador apareceu coroado e sentado em um trono, mas excepcionalmente cedo (8-10). Os cônsules e o pretor estão paramentados com togas ornamentadas e joias brilhantes (5-20). O imperador e os membros do governo estão ridiculamente vestidos, de maneira exagerada, como se estivessem preparados para algum evento importante. Contudo, os oradores públicos estão ausentes, o que é bastante incomum (23-4). Confusão e ansiedade se instalam quando os representantes do Estado e o povo de repente debandam (27-30) decepcionados.

Aquele que responde, por sua vez, dá respostas mecânicas e que soam racionais, como se fosse um porta-voz do imperador trêmelo. ${ }^{18}$ Suas seis respostas ecoam o vago e agourento termo oı ßáßapoı (no nominativo), repetido seis vezes como

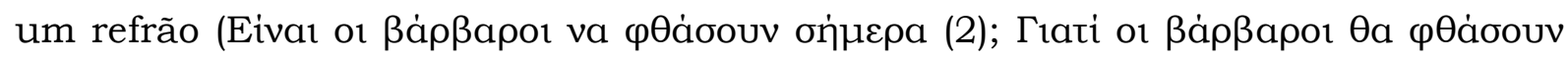

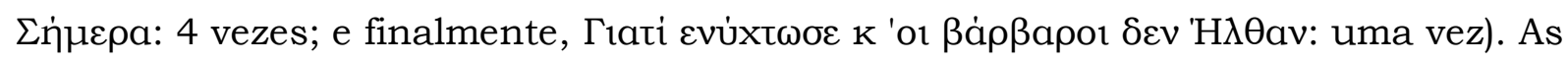
respostas invocam os esperados bárbaros como uma espécie de força da natureza, um poder estrangeiro que surge de fora e possui desejos e tendências específicas: ${ }^{19} \mathrm{a}$

\footnotetext{
15 Dimiroulis (2013), p. 85.

16 Boletsi (2013), p. 147. Com a exceção dos dois versos finais do poema, a voz que questiona fala em iâmbico com 15 sílabas, enquanto o que responde, em iâmbico de 13 sílabas; cf. Boletsi, op. cit., p. 174.

17 Cf. Dimiroulis, op. cit., pp. 89-90.

18 Boletsi, op. cit., pp. 147-8.

19 Dimiroulis op. cit., p. 90.
} 
predileção por títulos e cerimônias, o gosto pelas joias, a indiferença pela retórica pública, o pilar do governo. Os bárbaros, criaturas do desejo, são pintados em cores desagradáveis. Mas igualmente os não-bárbaros são incômodos, por seus funcionários abandonarem a austeridade Romana e estarem esperando, passivamente, pela invasão de "outros". Eles desejam os bárbaros - mas, como a voz que responde ressalta, citando testemunhas, eles não estão mais na fronteira. Como M. Boletsi coloca, "A estrutura racional e simétrica perfeita do poema colapsa no final. A não chegada dos bárbaros priva a civilização de sua única resposta que parecia ter e desautoriza o segundo interlocutor."20

É importante ter em mente aqui que os romanos eram "forasteiros" em relação aos gregos e, sem dúvida, na imaginação de Kaváfis, eles mesmos eram quasebárbaros, tendo conquistado a Hélade, depois de derrotar as forças da Federação Aqueia em Corinto, em 146 a. C. Dezoito anos mais tarde, Kaváfis alude a esta

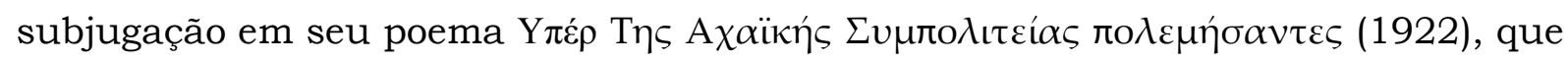
é um tipo de lamento sobre a queda do Peloponeso. ${ }^{21}$ Entretanto, esse poema lamenta mais do que a queda da Grécia continental no segundo século a. C. O prêmio Nobel de Literatura, Giorgos Seferis ${ }^{22}$ acrescentou importância ao fatídico ano de

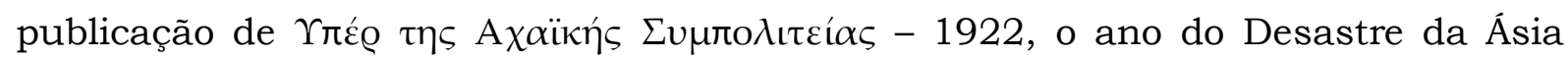
Menor (uma verdadeira limpeza étnica). Ptolomeu Latiros, cujo reino oferece a moldura temporal do epitáfio fictício, morreu em 81 a.C., cerca de 35 anos das forças de Júlio César sitiarem Alexandria e, supostamente, terem queimado a sua biblioteca. Assim, esse poema subsequente pode lançar luz sobre as camadas de decadência em "À espera dos bárbaros". Os romanos arrancaram a cortina da liga do

\footnotetext{
${ }^{20}$ Boletsi op. cit., p. 148.

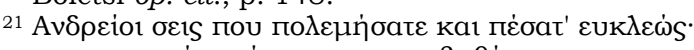

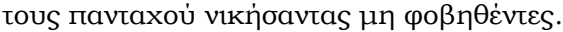

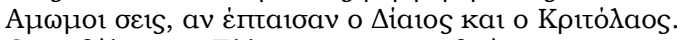

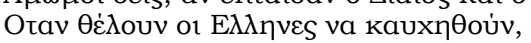

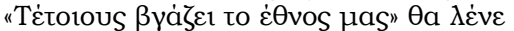

yı oas. Etor Өaupáoros Өávaı o énaıvós oas. --

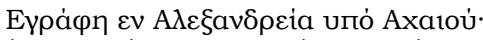

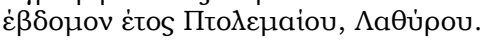

Os que combateram pela Federação Acaia

Valentes sois vós que combatestes e tombastes gloriosamente;

Sem temer os que venceram por toda a parte.

Diaio e Critolau falharam, mas irrepreensiveis sois vós.

Quando os gregos quiseram vangloriar-se,

"Tais homens produz nossa nação" dirão

de vós. Assim, admirável será vosso elogio. -

Foi escrito em Alexandria por um aqueu;

Sétimo ano do reinado de Ptolomeu Latiro. (trad. de FONSECA, 2006, p. 269). 
Peloponeso e do império grego ptolemaico do mesmo modo que os Turcos de Kemal destruíram o mundo grego na parte que hoje é a Turquia ocidental. ${ }^{23}$. No poema posterior, talvez "romanos" equivalham a "turcos". Isso necessariamente significa que "bárbaros" em Kaváfis é uma cifra para algo?

Mas volto ao poema "À espera dos bárbaros". O poema termina com uma declaração - daquele que pergunta - em exclamação (mas a qual os tradutores,

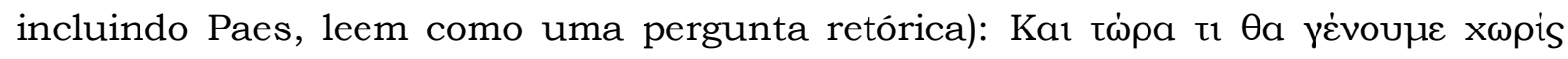

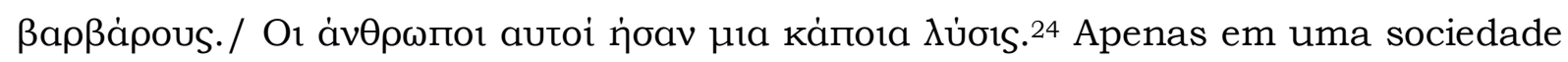
cuja cultura é decadente, os Bárbaros poderiam oferecer uma "solução" ou "libertação" (o duplo significado de גúoıs). Os atenienses de Temístocles despertaram, eles mesmos, contra os bárbaros, convocando uma antítese irreconciliável, democracia versus despotismo. A sociedade imperialista de Kaváfis, longe de se opor aos bárbaros, os deseja - e imita. Essa comunidade igualmente ainda os imita, uma vez que a repetição da palavra "bárbaros" lembra sua incompreensivel fala. O segundo orador, o qual repete a palavra seis vezes, fala como um bárbaro. ${ }^{25}$ Talvez o poeta entenda que o grego e o romano, depois de certo ponto, tornaram-se decadentes e próximos à cultura bárbara. Seu Império Romano de $\varphi \imath \lambda o \beta a ́ \rho \beta a \rho o r$ decadente poderia ser muito bem os dos Europeus ocidentais, particularmente como os que são retratados por escritores do fin de siècle como Huysmans, Mallarmé e Verlaine. Talvez Kaváfis, em um tom irônico, estivesse criticando o que ele via como um lapso total de decadência ("barbarismo") na Europa ou no Egito enquanto colônia Britânica. ${ }^{26}$ A Grécia também evocou um clima de incerteza e decadência. Os gregos estavam imersos em uma crise nacional em 1904, quando "Bárbaros" foi publicado: o Reino da Grécia havia há pouco começado uma campanha de guerrilha contra o controle de búlgaros e sérvios na Macedônia, naquele momento, sob dominação otomana. Creta estava sob administração internacional após uma guerra desastrosa contra os otomanos, lutando ainda para se tornar parte da Grécia. O império otomano foi rapidamente minguando. De qualquer maneira que nós leiamos o poema, fica claro que, na sociedade antiga, o conceito de "bárbaro" pressupunha um diálogo mental e uma relação conceitual, os quais Kaváfis dramatizou em seus "bárbaros"; e que esta relação dialógica demarcou o "nós" em relação ao "eles" no poema. Para os antigos, o espectro de sua identidade admitia gradações e "áreas cinzentas", algumas

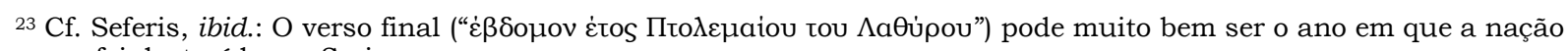
grega foi destruída em Smirna.

${ }_{24}$ Boletsi, op. cit., p. 173 ingenuamente defende a tese de que essas linhas enigmáticas são ditas pelo primeiro interlocutor. Cf. Dimiroulis, op. cit., pp. 97-8 sobre o ponto-final na penúltima linha.

${ }^{25}$ Boletsi, op. cit., 148.

${ }^{26}$ Dimiroulis, op. cit., pp. 76, 80, e Boletsi, op. cit, p.156, sobre bárbaros como europeus na Europa, fracassados rebeldes egipcios anti-coloniais ou nem tanto, os britânicos no Egito.
} 
vezes, aproximando-se da "Alteridade". Para Kaváfis, do mesmo modo, os "outros" poderiam realmente ser um aspecto de uma sociedade ou corpo político, ou ainda seu alter ego. ${ }^{27}$ Os seus bárbaros desapareceram da fronteira porque, na realidade, eles estão dentro: "e gente recém-chegada das fronteiras/ diz que não há mais bárbaros".

Como se notou, seus cidadãos foram atraídos por essa alteridade. O desejo por um alter ego bárbaro assimilável pode refletir o desejo paradoxal de Kaváfis pelo regresso, o qual talvez pudesse, como ele esperava, criar uma confiança fresca e um novo começo. 28

\section{Referências bibliográficas}

Anson, E. M. 'Greek ethnicity and the Greek language. In: Glotta 85: 5-30, 2010.

Boletsi, M. Barbarism and its discontents. Stanford, 2013.

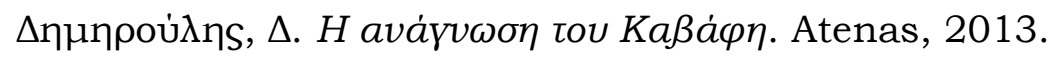

Dover, K. J. (ed.). Plato Symposium. Cambridge: CUP, 1980.

FONSECA, Ísis Borges (trad.). Poemas de K.P. Kaváfis. São Paulo: Odysseus, 2006.

Gruen, E. Rethinking the other in antiquity. Princeton, 2012.

Hall, E. Inventing the barbarian, Greek self-definition through tragedy. Oxford, 1989.

Hall, J. Hellenicity, Between ethnicity and culture. Chicago \& London, 2002.

Hillis Miller, J. Others. Princeton \& Oxford, 2001.

Mackie, H. S. Talking Trojan: Speech and community in the Iliad. Lanham, MD, 1996.

Momigliano, A. Alien wisdom: The limits of Hellenism. Cambridge, 1975.

Morgan, T. Literate education in the Hellenistic and Roman worlds. Cambridge, 1988.

\footnotetext{
${ }^{27}$ Ver, por exemplo, J. Hillis Miller (2001), sobre o "outro" como nosso alter ego.

${ }^{28}$ Aqui estou ampliando o comentário de Kaváfis sobre o poema também citado por Boletsi, op. cit., 174 e sua nota 36.
} 


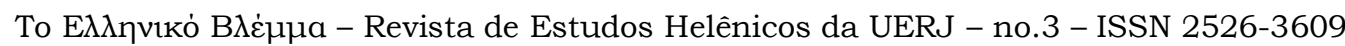

Ioannis Petropoulos - Universidade Democriteana da Trácia

Centro de Estudos Helênicos - Grécia, Universidade de Harvard

Prevelakis, G. Who are we? The geopolitics of Greek identity.(tr. Petropoulos, J.C.B). Athens, 2017.

Seferis, G. $\Delta o \kappa \iota \mu \dot{s}$. Atenas, 1974. vol. 1. 